\title{
Effects of organic amendments on soil biota on a degraded rangeland
}

\author{
WALTER G. WHITFORD, EARL F. ALDON, DIANA W. FRECKMAN, YOSEF STEINBERGER, AND LAWRENCE W. PARKER
}

\section{Abstract}

Rehabilitation of degraded rangeland requires rebuilding the soil, including soll biota. In this study wheat straw, bark and wood chips, and dried municipal sludge were placed on native range plots in northeentral New Mexico.

Organic amendments had little or no effects on decomposition of straw, litter respiration, soil respiration, biomass of soil microflora, and populations of most of the soll biota in the second year of the study. The differences in soil nematode and microarthropod population densities and straw decomposition occurred only in the bark and wood chip mulched plots in year 1 . The absence of differences in year 2 may have been the result of below-average rainfall. The wood chip bark mulch was visibily present at the end of year 2 but the other mulches were not. There may be long-term benefits from application of recalcitrant mulches like wood chips and bark, but the less recalcitrant mulching materials like straw and low application rates of sludge produce no measurable benefit.

Key Words: organic amendments, rangelands microarthropods, soil nematodes, soil microflora

Decomposition and mineralization are essential processes in nutrient cycles in ecosystems. The rates of these processes are regulated by the activity of soil animals that feed on the soil microflora (Ingham et al. 1985, Parker et al. 1984a). In arid and semiarid ecosystems, the activity of the soil biota is often limited by moisture availability and available organic matter (Steinberger et al. 1984). Added organic matter may effect soil biota activity more than soil moisture (Steinberger et al. 1984, Parker et al. 1984b). Since semiarid ecosystems are nitrogen- (West and Skujins (1978) as well as water-limited, manipulations that stimulate increased rates of $\mathrm{N}$ availability should increase productivity of the system. Degraded rangelands subject to soil erosion are characterized by decreased rainfall infiltration, reduced buffering of soil temperatures (Johnston et al. 1971), and changes in the soil biota.

Regeneration of the perennial grasses on degraded ranges may require rebuilding the soil, including soil biota. We hypothesized that addition of organic materials to degraded rangeland soils would (a) stimulate activity of the soil biota and (b) increase soil organic matter and soil nutrients, especially nitrogen, by providing an energy source for free living nitrogen fixers. This in turn would modify the physical environment, i.e., infiltration and soil temperatures. This study was designed to examine soil ecosystem changes resulting from addition of organic materials to degraded blue grama (Bouteloua gracilis) grass rangeland on the Rio Puerco watershed in northcentral New Mexico. The Rio Puerco Watershed is a semiarid basin in northcentral New Mexico. The

\footnotetext{
Authors are with the Department of Biology, Box 3AF, New Mexico State University, Las Cruces 88003; USDA Forest Service-Rocky Mountain Forest and Range Experiment Station, 2205 Columbia SE, Albuquerque, N. Mex, 87106; Department of Nematology, University of Califormia, Riverside 92502; Biology Department, Bar-Ilan University, Ramat-Gan, Israel; Westbridge Agro Products, 9920 Scripps Lake Drive, San Diego, Calif. 92131, respectively.

This reseach was supported by the Rocky Mountain Forest and Range Experiment Station, USDA Forest Service, and National Science Foundation Grants DEB8215357 to Freckman and DEB8215359 to Whitford. This work was conducted in cooperation with the USDI-Bureau of Land Management, which furnished funds and field study locations.

Manuscript accepted 8 August 1988.
}

watershed has a long history of settlement, heavy livestock grazing, and site degradation which began in the mid-to late 1700's (Calkins 1937, Dortignac 1960, Vincent 1984).

\section{Material and Methods}

\section{Field Layout}

The study design was a completely randomized block in which the 4 blocks were perpendicular to the slight (3\%) slope of the terrain. Each block contained four $30 \times 40-\mathrm{m}$ plots assigned at random within the block to one of the following treatments: no organic mulch (control), wheat straw mulch at $2 \mathrm{Mg} \mathrm{ha}^{-1}$, bark and wood chip mulch at $2 \mathrm{Mg} \mathrm{ha}^{-1}$, and dried Albuquerque municipal sewage sludge at $1 \mathrm{Mg} \mathrm{ha}^{-1}$. The $\mathrm{C}: \mathrm{N}$ ratios of the mulches were: straw-143, wood chips and bark-327, sewage sludge-8.8. Mulches were applied to the surface covering $60-70 \%$ of the surface area. There was limited redistribution of the straw mulch with some accumulation around shrubs. By May of year 2 the only visible mulch was the wood-bark amendment. The plots were sampled twice initially, once in mid-September (1980) 5 days prior to mulch application, and in late September, 5 days after application, and then at 30- to 40-day intervals following treatment during the first year (1981) except when roads were impassable. During the second year (1982) plots were sampled in winter, early dry season (May), twice in the summer wet growing season, and once in early winter. Rainfall data were obtained from a storage rain gauge installed prior to the installation of the study.

On each sampling date, soil cores $6 \mathrm{~cm}$ in diameter were taken 15 cm deep within 3 hours after sunrise. Paired cores were sampled for extraction of microarthropod and nematodes with 3 replicate sets of cores ( 2 soil cores per set) from each plot. The sampling locations were determined by selecting random coordinates from a $1-m$ grid of each plot. At the sample site location, the mulch was gently moved from the soil surface before cores were taken. A small subsample was removed at $6 \mathrm{~cm}$ from each core site and placed in a tared soil tin for gravimetric water content and organic matter.

\section{Sample Processing-Soil Biota}

The soil cores were transported to the laboratory in insulated containers. One core for each sample site was placed in a Tullgren funnel extractor; microarthorpods were extracted onto water and counted (Santos and Whitford 1981). This provided 3 counts of microarthropods per block. The second core was mixed and subjected to sugar flotation-sieving technique to extract the nematodes (Freckman et al. 1977). Nematodes were identified, counted, and placed in 1 of 4 trophic groups: fungivores, bacterivores, plant feeders, or omnivore-predators. Soil and litter respiration were measured by absorbing $\mathrm{CO}_{2}$ into jars of $\mathrm{NaOH}$ placed under inverted coffee cans (Parker et al. 1984b).

Every third month an additional soil core was taken at each sample site for the estimation of soil microflora and protozoa biomass. Total soil nitrogen was measured from these samples by micro-Kjeldahl digestion (Bremner 1965, Thomas et al. 1967). Protozoan populations were estimated by the most probable number method described by Singh (1946). Bacterial numbers were estimated by fluorescein isothiocyanate direct counts (Babiuk and Paul 1970) and fungi by direct count and hyphal volume estimates that were converted to biomass using the conversions in Jones and Mollison (1948). 


\section{Vegetation}

Aboveground plant biomass was harvested on twelve $0.25-\mathrm{m}^{2}$ quadrats on each plot in September of each year to obtain estimates of biomass production for the previous growing season. Quadrat locations were randomly based on the grid system described previously.

\section{Decomposition Rates}

Rates of decomposition were compared by placing fiberglassmesh litter bags containing wheat straw on the soil surface plots (Crossley and Hogland 1962). Five bags from each treatment were collected in the first year after 3 months, 6 months, and 9 months in the field. Decomposition was measured by oven-dry weight loss of litter bag contents. In the second year, 40 litter bags were buried at $5 \mathrm{~cm}$ deep on each plot on one block. The bags were removed at the end of this second year. Mass loss from the litter bags was measured using the soil infiltration correction method (Elkins and Whitford 1982).

An analysis of variance and Duncan's multiple range test were used for determining individual treatment differences $(p=0.05$ or 0.01 level) on each of the 14 sampling dates during the study period.

\section{Results}

Differences in total and seasonal rainfall in the 2 years of the study may have had some effect on the results. The seasonal rainfall was as follows: winter 1980 to $1981-88.1 \mathrm{~mm}$; summer $1981-312.9 \mathrm{~mm}$, winter 1981 to $1982-141.5 \mathrm{~mm}$; and summer 1982-199.9 mm, providing a much drier second year growing season. The long-term (18 years) average rainfall during the growing season is $177 \mathrm{~mm}$ and $87 \mathrm{~mm}$ in the winter (Aldon and Garcia 1973).

Initial statistical analysis showed no significant block effects for any of the parameters measured; therefore, data from all blocks were pooled for subsequent analyses.

The bark and straw mulch treatment reduced the loss of soil

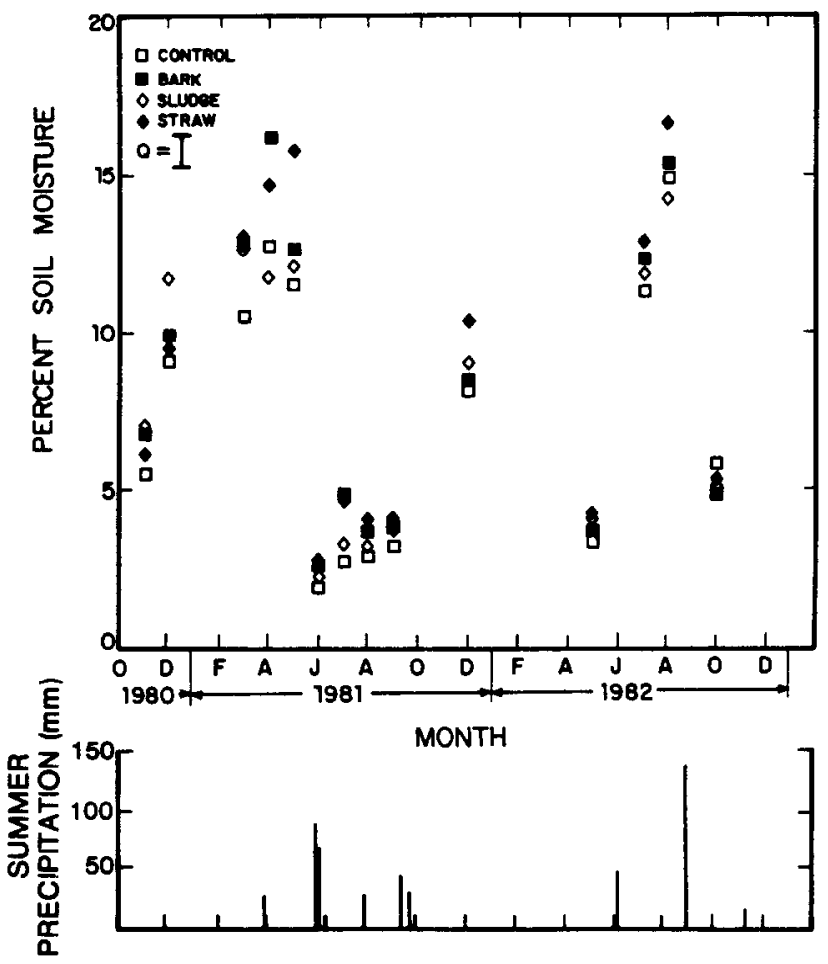

Fig. 1. Comparisons of gravimetric soil moisture on plots subjected to mulching with organic materials. Values separated more than $Q$ are significantly different $(\mathrm{p}<.05)$. moisture, resulting in higher soil moisture contents during most of the study period (Fig. 1). The sludge amendment treatment resulted in significantly higher soil moisture content only during the cooler months. There were no significant differences in soil organic matter due to the mulches and amendments. The mean organic matter content for all soils was $3.81 \% \pm 0.24 \%$.

The organic amendments had slight effects on the rates of decomposition. Straw in the litter bags placed on the surface lost significantly more mass on the bark and wood chip mulched plots than on plots mulched with straw $(p<0.01)$, although this difference was present only in June and December (Fig. 2). Decomposition of straw placed on the surface at the end of the first year

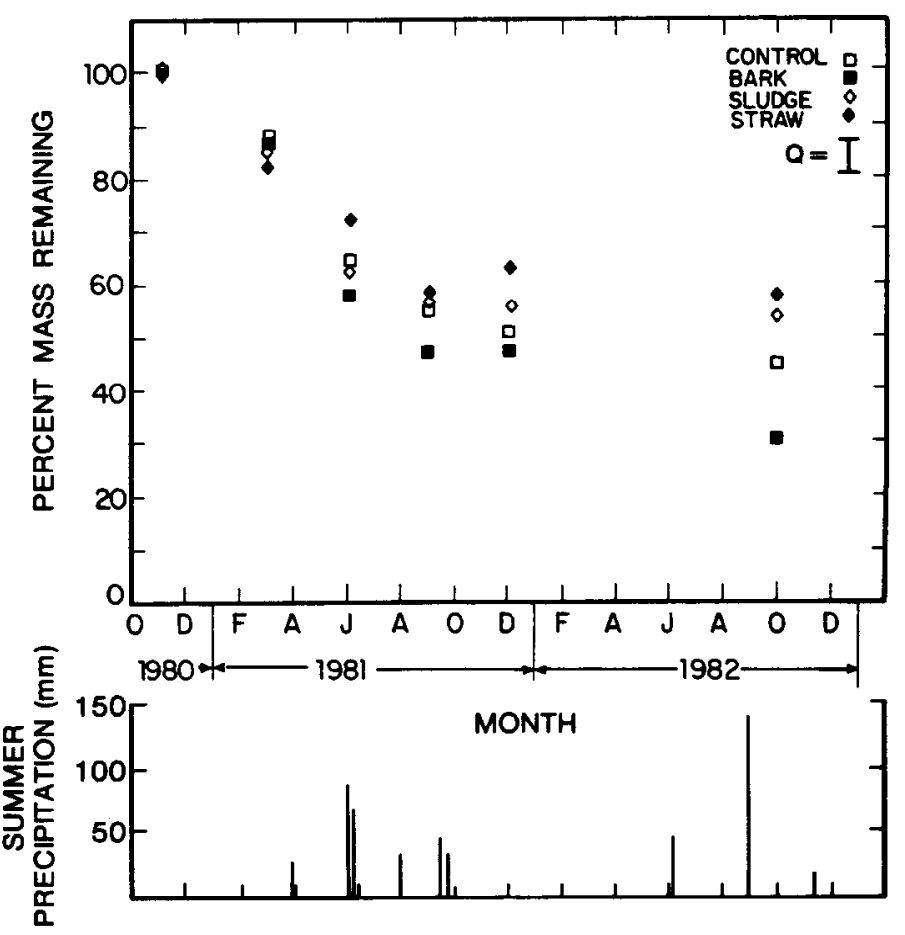

Fig. 2. Effects of organic mulches on straw decomposition. Values separated more than $Q$ are significantly different $(\mathrm{p}<.05)$.

exhibited no significant differences attributable to the mulches. Mass losses averaged $12.9 \% \pm 7.0 \%$ during the second year. There were significantly lower rates of mass loss under the straw mulch than under the bark mulch. The following percent mass losses were found: unamended, 18.2 \pm 5.1 ; straw mulch, $11.0 \pm 3.2$; bark and wood chip mulch, $17.7 \pm 4.1$; and sludge mulch, $21.2 \pm 5.0$ $(p<0.01)$.

The organic amendments had no effect on litter respiration $(p>0.3)$. Respiration of microbes and soil fauna in the litter ranged from $4 \mathrm{mg}$ to $9 \mathrm{mg} \mathrm{CO} \mathrm{m}^{-2} \mathrm{~h}^{-1}$. The litter respiration was orders of magnitude lower than soil respiration (Fig. 3). Straw and bark amendments affected soil respiration during the first year, but with inconsistent patterns (Fig. 3). In addition the amendments produced greater variability during the first year when the coefficients of variation on the amended plots averaged $52.5 \%$ for litter respiration and $\mathbf{9 7 . 9 \%}$ for soil respiration. On the unamended plots the coefficients of variation during the first year averaged $5.3 \%$ and $38 \%$ respectively. During the second year coefficients of variation were low for both litter and soil respiration; $4.4 \%$ and $33.1 \%$ respectively.

The organic mulches had no effect on the soil microflora biomass or on soil protozoan populations. There were no statistically significant differences in these parameters through time (Table 1). Organic mulches resulted in increases in soil nematode fauna 
Table 1. Average numbers plus or minus one standard deviation of protozoans and biomass of microflorn on the plots amended with the organic mulches Indicated.

\begin{tabular}{|c|c|c|c|c|}
\hline & Straw & Bark & Control & Sludge \\
\hline $\begin{array}{l}\text { Protozoans } \mathrm{No}^{-1} \text { dry soil } \\
\text { Bacteria mg } \mathrm{C}^{-1} \text { dry soil } \\
\text { Fungi mg C } \mathrm{g}^{-1} \text { dry soil } \\
\text { Yeast } \mathrm{mg} \mathrm{C} \mathrm{g}^{-1} \text { dry soil }\end{array}$ & $\begin{array}{c}47,334 \pm 15,183 \\
39.1 \pm 9.0 \\
201.2 \pm 153.3 \\
107.7 \pm 76.5\end{array}$ & $\begin{array}{c}46,354 \pm 16,267 \\
41.8 \pm 15.2 \\
154.9 \pm 100.3 \\
108.2 \pm 36.8\end{array}$ & $\begin{array}{c}43,125 \pm 16,064 \\
46.0 \pm 16.3 \\
214: 6 \pm 149.6 \\
111.5 \pm 38.0\end{array}$ & $\begin{aligned} 47,723 & \pm 23,189 \\
48.0 & \pm 31.6 \\
234.8 & \pm 167 \\
103.3 & \pm 48.8\end{aligned}$ \\
\hline $\begin{array}{l}\text { Protozoans } \\
\text { Bacteria } \\
\text { Fungi } \\
\text { Yeast } \\
\end{array}$ & $\begin{array}{l}\mathrm{F}_{3,8}=1.37 p>0.31 \\
\mathrm{~F}_{3,9}=0.85 p>0.50 \\
\mathrm{~F}_{3,9}=0.88 p>0.49 \\
\mathrm{~F}_{3,9}=1.30 p>0.33\end{array}$ & & & \\
\hline
\end{tabular}

populations during the first growing season (Fig. 4) $(p<0.01)$, but there were no significant differences in nematode populations on treatment plots during the second growing season $(p>.5)$. Before the application of organic mulches, the nematode trophic structure was $5.6 \%$ fungal feeders, $48.0 \%$ bacterial feeders, $3.3 \%$ omnivore predators, and $22.9 \%$ plant parasitic nematodes. There were no changes in percent composition of the soil nematode populations attributable to the organic mulches. The average and range of

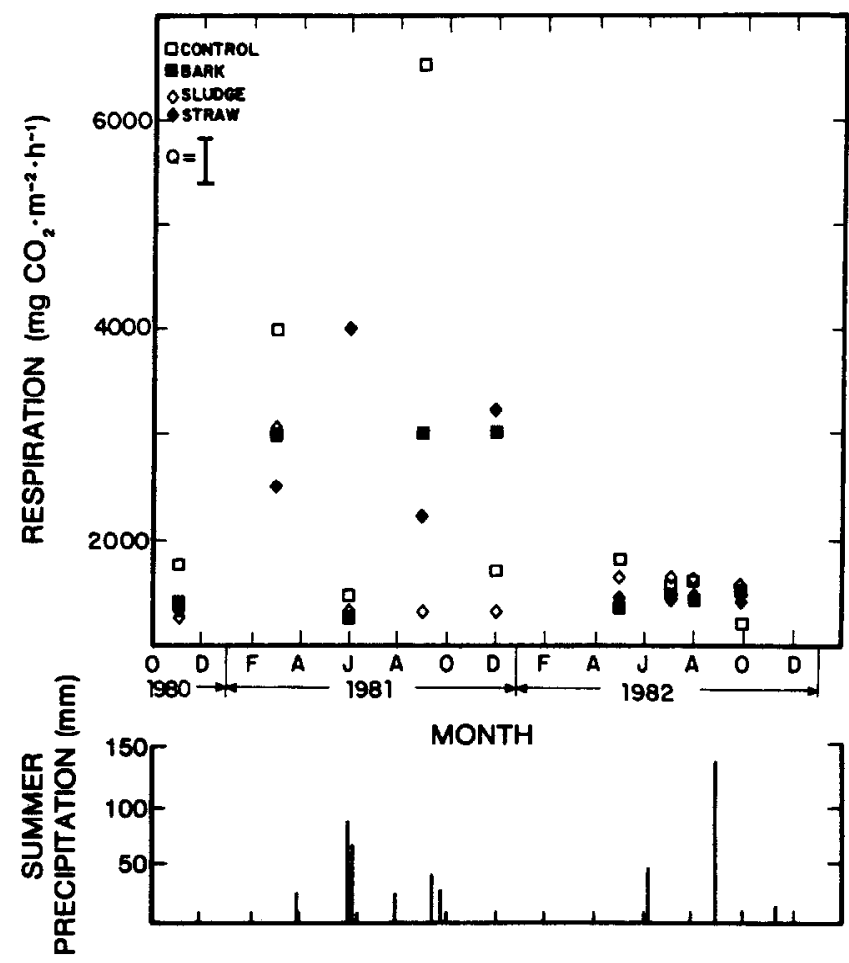

Fig. 3. Effects of organic mulches on soil respiration. Values separated more than $Q$ are significantly different $(p<.05)$.

percentages of each trophic group of soil nematodes during the 2 treatment years were as follows: fungal feeders, $\bar{x}=9.5 \%, 2.3-18 \%$; bacterial feeders, $\bar{x}=45.2 \%, 35.0-59.3 \%$, omnivore-predators, $\bar{x}=$ $15.3 \%, 9.5-32.3 \%$ plant parasites, $\bar{x}=22.4 \%, 12.1-29.5 \%$. Nematodes already dead or damaged during extraction made up part of each sample; hence the summed proportions do not equal $100 \%$. The plant parasitic nematode taxa were extremely diverse for this habitat. The following genera of plant parasitic nematodes were associated with Bouteloua gracilis on the site: Criconemoides sensu lato, Ditylenchus spp., Helicotylenchus spp., Merlinius spp., Nothotylenchus spp., Quinisulcius spp., Tylenchus spp., and Xiphinema spp. All of these genera are obligate ectoparasitic nematodes except for Ditylenchus, Nothotylenchus, and Tylenchus,

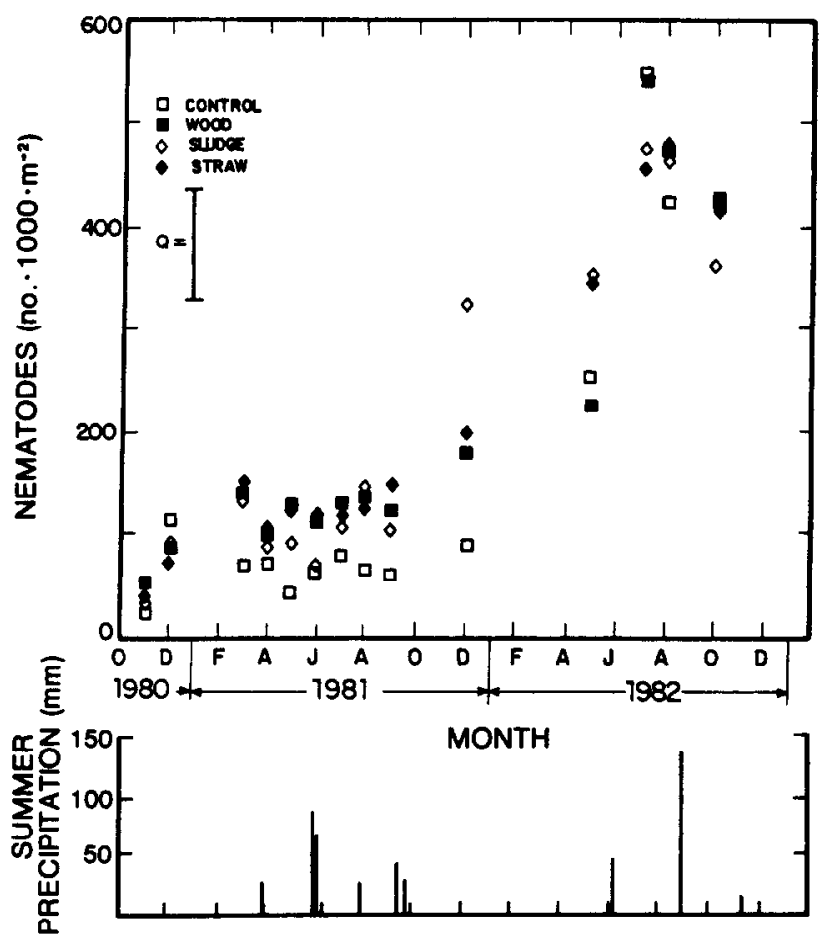

Fig. 4. Effects of organic mulches on free living nematode populations. Values separated more than $Q$ are significantly different $(p<.05)$.

which are considered to be faculative plant parasites/fungivore.

The organic mulches had few effects on the soil microarthropod populations (Figs. 5 and 6). On a few dates in the first summer, total numbers of microarthropods were significantly higher in bark and wood chip mulched soils compared with other treatments but not higher than the controls. Microarthropod populations in December 1981 were significantly greater in the bark and wood chip mulched soils.

The significant differences in microarthropod populations were due to responses of several groups of prostigmatid mites (Fig. 6). The Prostigmata responding to the organic amendments during the first growing season were pygmephorids, tarsonemids, and tydeids. There were no effects of the mulches on cryptostigmatid or mesostigmatid mites; however, there were seasonal patterns of abundance.

During the first growing season the Prostigmata were dominated by small fungus-feeding or omnivorous mites; approximately $30 \%$ tydeids and $60 \%$ fungus-feeding tarsonemids and pygmephorids. During the second growing season tydeids and tarsonemids made up approximately $50 \%$ of the Prostigmata, with nanorchestids accounting for about $20 \%$ and pygmephorids less than $5 \%$. 


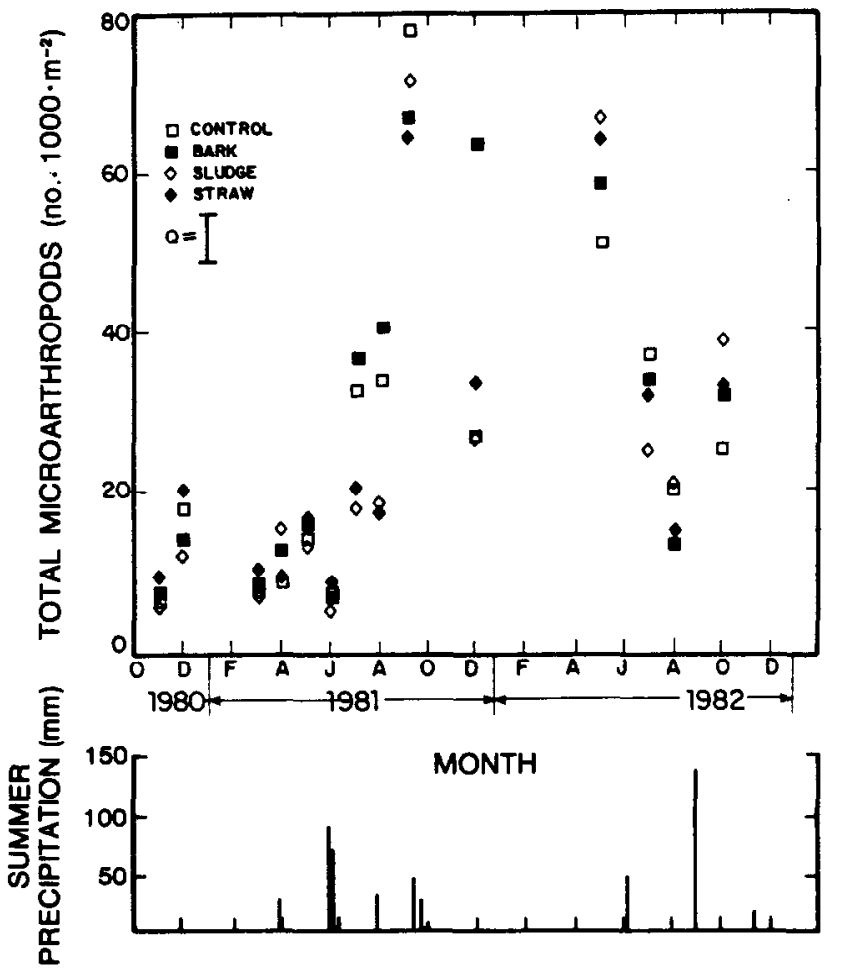

Fig.5. Effects of organic mulches on total microarthropods. Values separated more than $Q$ are significantly different $(p<.05)$.

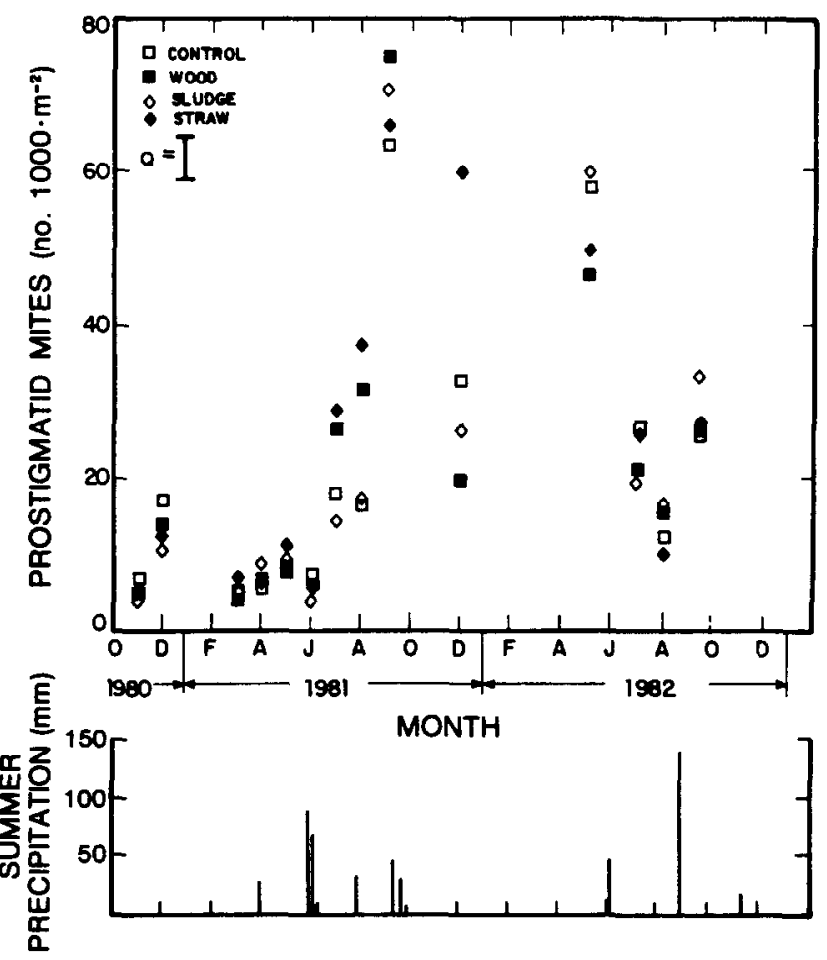

Fig. 6. Effects of organic mulches on prostigmatid mites. Values separated more than $Q$ are significantly different $(\mathrm{p}<.05)$.

The pretreatment soil nitrogen was $1.75 \pm 0.53 \mathrm{mg} \mathrm{g}^{-1}$ dry soil with a range among plots of $1.4 \pm 2.1 \mathrm{mg} \mathrm{g}^{-1}$ dry soil. There were not significant differences in soil nitrogen among treatments following amendments.

There was a significant increase in net blue grama grass production on the bark and wood chip plots at the end of the first growing season. There were no significant differences in blue grama production at the end of the second year (Table 2). Net production in the second year was considerably lower than year one, probably due to the lower rainfall during the second growing season.

Table 2. Comparison of net production of Boutelowa graclits and forbs on the mulched plots and control at the period of peak standing crop (am $\left.\mathbf{m}^{-1}\right)$.

\begin{tabular}{lccccc}
\hline \hline & \multicolumn{2}{c}{1981} & \multicolumn{2}{c}{1982} \\
\cline { 2 - 3 } & B. gracilis & Forbs & B. gracilis & Forbs \\
\hline Straw & 60.0 & 43.7 & 14.4 & 2.1 \\
Bark & $109.9^{*}$ & 46.5 & 15.7 & 1.8 \\
Sludge & 46.7 & $85.8^{*}$ & 12.3 & 5.0 \\
Control & 68.5 & 50.0 & 14.8 & 5.3 \\
\hline
\end{tabular}

-Indicates significant difference at $p<0.05$.

\section{Discussion}

The most important result this study found was the short duration of changes in soil biota resulting from the addition of low levels of organic mulches. In a study on the effects of organic amendments on soil biota and decomposition in strip-mined spoils, Elkins et al. (1984) found dramatic effects from the addition of wood chip and bark on decomposition and soil microfauna. The study by Elkins et al. (1984) was conducted during one growing season on sites that had been amended with organic mulches 2 years prior to their study. The results of the first year of this study were consistent with those obtained by Elkins et al. (1984) with respect to the efficacy of recalcitrant organics in affecting decomposition rates, some taxa or microarthropods, and net production. The second growing season of this study was drier than the first, with $100 \mathrm{~mm}$ less rainfall than in the first year. The drier conditions may have affected the soil microflora and microfauna populations more than the organic mulches. An alternate explanation is that in this study, the organic mulches were applied to the soil surface in an area with preexisting vegetation and presumably a reduced but viable microflora and microfauna population. Initially, the organic mulches may have added a pulse of substrate for these organisms, hence increasing soil respiration.

The fact that the microfloral biomass appeared unaffected by the mulches despite increased soil respiration was probably due to grazing by nematodes (Santos et al. 1981, Ingham et al. 1985) and fungal-grazing pygmephorid and tarsonemid mites (Parker et al. 1984a), which did increase after the first year. Fungal grazing by these mites has been shown to be important in nitrogen mineralization (Parker et al. 1984a). The relationship between soil respiration and microbial biomass indicates high microbial biomass turnover stimulated by the mulch addition. The activity of the soil biota is more important than the population densities for decomposition and mineralization. The increases in microfloral grazers, increased soil respiration, and stable microfloral biomass is consistent with the idea that grazing by populations of nemotodes or mites may stimulate the activity of microbial populations and stimulate mineralization (Ingham et al. 1985). The lack of detectable change in soil nitrogen does not mean that there were no changes in plant available $\mathrm{N}$. Total $\mathrm{N}$ is a measure of standing stock and does not indicate the rate of $\mathrm{N}$ mineralization. Current methods for examining rates of $\mathbf{N}$ mineralization are indirect laboratory incubations that are not applicable to field experiments, hence were not used in this study. In the absence of direct measures, soil respiration as an index of microbial activity can also be viewed as an index of $\mathbf{N}$ mineralization.

Bartolome et al. (1980) found that natural mulch stimulated 
forage production on some sites in a California annual rangeland but did not influence standing crop in regions receiving less than $250 \mathrm{~mm}$ of mean annual precipitation. The data of Bartolome et al. (1980) suggest that the lack of continued effect of mulches in this study conducted on the rangelands near Cuba, N. Mex., may have been due to the drier conditions during the second year.

We anticipated that the addition of sewage sludge would produce an immediate increase in available $\mathrm{N}$, thereby stimulating both net production and activity of soil microflora (Magdoff and Amadon 1980). The small effect of sludge on the soil biota suggests that nitrogen losses may have equaled the nitrogen inputs from the sludge. The general increase in nematode numbers on the plots in year 2 reflects the increased resources resulting from the wet summer in year 1 . The lack of significant differences in the relative proportions of the nematode trophic groups over time and treatment indicates an increase in resources for all the nematodes. The trophic structure differed from other arid sites (Freckman and Mankau 1986, Steinberger et al. 1984) by having lower numbers of omnivore predators and greater densities of plant parasites. The densities of nematodes recovered from this study were an order of magnitude lower than those reported by Stanton et al. (1984) in blue grama grasslands in Colorado, although the percentage of plant parasitic nematodes falls within the range they reported. The diversity of plant parasitic nematode species and their densities are considerably higher than seen in Larrea-dominated rangelands in southern New Mexico (Steinberger et al. 1984, Freckman et al. 1987).

The maximum densities of microarthropod found in these studies were equivalent to the average densities reported on burned sites in tallgrass prairie (Seastedt 1984). The average densities were closer to those reported in deserts (Steinberger et al. 1984, Wallwork et al. 1985, Kamill et al. 1985), and the taxonomic composition, i.e., dominance of prostimatid mites, were more like desert than grassland. The greater number of small fungal-feeding acari such as tarsonemids, especially in the wood and straw mulched soils, was probably attributable to the increased activity of fungi and the more moist soil conditions.

In order for a mulch to serve as a stimulant for soil biotic activity, the material should slowly release organic particles that can serve as an energy source for the microflora and modify the soil physical environment which can benefit the microfauna. Bark and wood chips were still present as a visible mulch at the end of 2 years providing physical modification as well as chemical modification to the soil. Unlike cultivated agricultural environments where $\mathbf{N}$ immobilization by high $\mathrm{C}: \mathrm{N}$ ratio materials is undesirable, in semiarid rangelands where moisture availability affects both $\mathrm{N}$ immobolization and mineralization, high $\mathrm{C}: \mathrm{N}$ ratio mulches can be beneficial. This is largely due to the grazing of fungi by microarthropods whose activity is independent of soil moisture (Steinberger et al. 1984). This grazing activity will result in mineral $N$ that is available to plants (Parker et al. 1982a).

\section{Literature Cited}

Aldon, Earl F., and George Garica. 1973. Seventeen-year sediment production from a semi-arid watershed in the Southwest. USDA Forest Serv. Rocky Mountain Forest and Range Exp. Sta., Res. Note RM-248.

Babiuk, L.A., and E.H.Paul. 1970. The use of fluorescein isothiocyanate in the determination of the bacterial biomass of a grassland soil. Can. J. Microbiol. 16:57-62.

Bartolome, J.W., M.C. Stroud, and H.F. Heady. 1980. Influence of natural mulch on forage production on differing California annual range sites. J. Range Manage. 33:4-8.
Bremner, J.M. 1965. Total nitrogen. p. 1149-1178. In: C.A. Black, (ed.) Methods of soil analysis. Amer. Soc. Agron., Madison, Wis.

Calkins, H.G. 1937. A report on the Cuba Valley. USDA Soil Conserv. Serv., Reg. 8, Reg. Bull. No. 36. Albuquerque, N. Mex.

Crossley, D.A., Jr., and M.P. Hogland. 1962. A litter bag method for the study of microarthropods inhabiting leaf litter. Ecology 43:571-573.

Dortignac, Edward J. 1960. The Rio Puerco-past, present, and future. New Mexico Water Conference Proc. 5:45-51.

Elkins, Ned Z., and W.G. Whitford. 1982. The role of microarthropods and nematodes in decomposition in a semi-arid ecosystem. Oecologia 55:303-310.

Elkins, Ned Z., Lawrence W. Parker, Earl F. Aldon, and W.G. Whitford. 1984. Responss to soil biota to organic amendments in strip-mine spoils in northwestern New Mexico. J. Environ. Qual. 12:215-219.

Freckman, D.W., D.T. Kaplan, and S.D. Van Gundy. 1977. A comparison of techniques for extraction and study of anhydrobiotic nematodes from dry soil. J. Nematol. 9:176-181.

Freckman, D.W., and R. Mankau. 1986. Abundance, distribution, biomass, and energetics of soil nematodes in a northern Mojave Desert ecosystem. Pedobiologia 29:129-142.

Freckman, D.W., W.G. Whitford, and Y. Steinberger. 1987. Nematode population dynamics and activity in desert soils: effect of irrigation. Biology and Fertility of Soils. 4:129-135.

Ingham, Russell E., J.A. Trofymow, E.R. Ingham, and D.C. Coleman. 1985. Interactions of bacteria, fungi, and their nematode grazers: effects on nutrient cycling and plant growth. Ecological Mono. 55:119-140.

Johnston A., J.F. Dormarr, and S. Smollak. 1971. Long-term grazing effects on fescue-grassland soils. J. Range Manage. 24:185-188.

Jones, P.C.T., and J.E. Mollison. 1948. A technique for the quantitative estimation of soil microorganisms. J. Gen. Microbiol. 2:54-69.

Kamill, Bernardette W., Y. Steinberger, and W.G. Whitford. 1985. Soil microarthropods from the Chihuahuan Desert of New Mexico. J. Zool. Soc. Lond. (A) 205:273-286.

Magdoff, F.R., and J.F. Amadon. 1980. Nitrogen availability from sewage sludge. J. Environ. Qual. 9:451-455.

Parker, L.W., P.F. Santos, J. Phillips, and W.G. Whitford. 1984a. Carbon and nitrogen dynamics during the decomposition of litter an roots of Chihuahuan Desert annual Lepidern Ariocaupan. Ecol. Res. 54:339-360.

Parker, LW., D.W. Freckman, Y. Steinberger, L. Drigzers, and W.G. Whitford. 1984b. Effects of simulated rainfall and litter quantities on desert soil biota: soil respiration, microflora, and protozoa. Pedobiologia 26:267-274.

Santos, P.F., and W.G. Whitford. 1981. Litter decomposition in the desert. Bioscience 31:145-146.

Suntos, P.F., and W.G. Whitford. 1981. The role of mites and nematodes in early stages of buried litter decomposition in a desert. Ecology 62:664-699.

Seastedt, T.R. 1984. Microarthropods of burned and unburned tall grass prairies. J. Kans. Entomol. Soc. 57:468-476.

Singh, B.N. 1946. A method of estimating the number of soil protozoa especially amoebae, based on their differential feeding on bacteria. Ann. Appl. Biol. 33:112-119.

Stanton, Nancy L., Dennis Morrison, and William A. Laycock. 1984. The effect of phytophagous nematode grazing on blue grama die-off. J. Range Manage. 37:447-450.

Steinberger, Y., D.W. Freckman, L.W. Parker, W.G. Whitford. 1984. Effects of simulated rainfall and litter quantities on desert soil biota; nematodes and microarthropods. Pedobiologia 26:267-274.

Tansley, A.G.1935. The use and abuse of vegetational concepts and terms. Ecology 16:284-307.

Thomas, R.L., R.W. Sheard, and J.R. Moyer. 1967. Undivided/simultaneous determination of nitrogen and/or phosphorus. In: BD Acid Digests. Industrial Method No. 334-74W/B. Technicon Instruments Corp., Tarrytown, N.Y.

Wallwork, B.W., W.G. Kamill, and W.G. Whitford. 1985. Distribution and diversity patterns of soil mites and other microarthropods in a Chihuahuan desert site. J. Arid Environ. 9:215-231.

West, N.E., and J. Skujins. 1978. Nitrogen in Desert Ecosystem Dowden Hutchison and Ross Stroudsberg, Penn.

Vincent, Dwain. 1984. Range trend in the Cabezon area. Rangelands 6:120-122. 